\title{
MINERALOGY, GEOCHEMISTRY AND METAMORPHISM OF THE EARLY PROTEROZOIC VÄHÄJOKI IRON ORES, NORTHERN FINLAND
}

\author{
JUSSI LIIPO and KAUKO LAAJOKI
}

LIIPO, JUSSI AND LAAJOKI, KAUKO 1991: Mineralogy, geochemistry and metamorphism of the early Proterozoic Vähäjoki iron ores, Northern Finland. Bull Geol. Soc. Finland 63, Part 2, 69-85.

The Vähäjoki iron ores occupy the uppermost part of the Karelian (Early Proterozoic) quartzite-dolomite sequence deposited on the late Archaean basement in southern Lapland. The ores occur as magnetite veins brecciating dolomite and as magnetite disseminations in chlorite and mica schists. Their average iron content is $40 \%$, and they contain up to $3.8 \% \mathrm{P}_{2} \mathrm{O}_{5}$, features which together with the division of the ores into 14 small bodies make them uneconomic.

The only main ore mineral is magnetite, with which there occur accessory ilmenite, haematite, pyrite, chalcopyrite, pyrrhotite, arsenopyrite and cobaltite with small gold inclusions. The main gangue minerals classified by microanalysis are dolomite or Fe-dolomite in the dolomites, ferri-tremolite, tremolite, ferri-actinolite and ferrian actinolite, cummingtonite, magnesio-hornblende and tschermakitic hornblende in amphibole-bearing hosts rocks, green $\mathrm{Mg}$-rich biotite, brown Fe-rich biotite and Ba-bearing ( $\mathrm{BaO} 0.18-7.9 \%)$ biotite, and chlorite in chlorite and mica schists.

Major and trace elements were analyzed in 18 samples. The dolomites contain $24-53 \% \mathrm{CaO}$ and $3-20 \% \mathrm{MgO}$, while the amphibole rocks, amphibole schists, chlorite schists and mica schists are chemically rather similar, containing about $13-27 \% \mathrm{Fe}_{\text {tot }}$ and $7-21 \% \mathrm{MgO}$, the amphibole-bearing varities being a little richer in these elements than the phyllosilicate-bearing ones. The ore samples from magnetite matrix of the breccia type contain $71-85 \% \mathrm{Fe}_{2} \mathrm{O}_{3}$ and $0.05-0.2 \% \mathrm{P}_{2} \mathrm{O}_{5}$.

The garnet-biotite and calcite-dolomite geothermometers and the mineral chemistry of the Ca-amphiboles suggest that the Vähäjoki iron ores were metamorphosed under greenschist - amphibolite facies conditions $\left(\mathrm{T}=465^{\circ} \mathrm{C}\right.$ and $\mathrm{P}=2-4$ $\mathrm{Kbar})$. Flunctiation in metamorphic grade is reflected in the change in amphibole composition from tremolite-actinolite to tschermakitic hornblende.

The Vähäjoki iron ores were remobilized and enriched during early Proterozoic regional metamorphism and deformation, forming an epigenetic iron ore.

Key words: iron ores, mineral composition, chemical composition, metamorphism, Proterozoic, Vähäjoki, Tervola, northern Finland.

Jussi Liipo and Kauko Laajoki: Department of geology, University of Oulu, 90570 Oulu, Finland.

\section{Introduction}

The Vähäjoki iron ores are located in two north-south trending zones, $3,5 \times 1,5 \mathrm{~km}_{2}$ in total area, the commune of Tervola (Figs. 1 and 2). They were found in 1938 and drilled for the first time in 1943 (drill holes Nos. 1-10). Prospecting was continued in 1959-1969 by the Otanmäki company, later the Rautaruukki company, which drilled holes Nos. 11-28. A third drilling period occurred in 1979-1982 when Lapin Malmi drilled holes Nos. 29-52. The total ore 


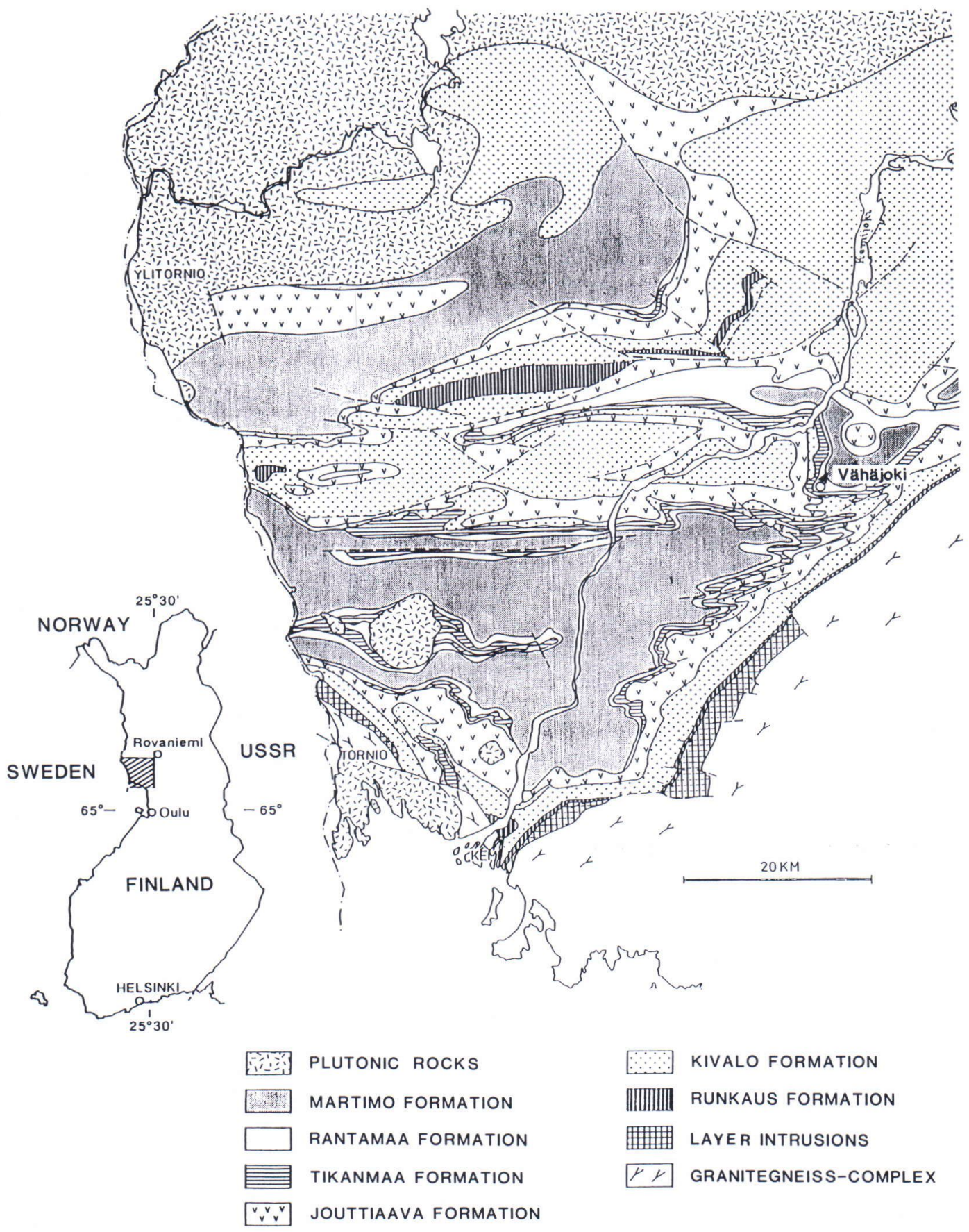

Fig. 1. Geological units of the Peräpohja area, after Perttunen (1989).

Fig. 2. Geological map of the Vähäjoki iron ore area after Korvuo (1982). Key to legend: $1=$ dolomite, $2=$ amphibolemica schist, $3=$ mica schist, $4=$ iron ore, $5=$ quartzite, $6=$ black schist, $7=$ basic tuff, $8=$ basic volcanite, $9=$ magnetite veins, $10=$ ball structure, $11=$ dolomite interlayers, $12=$ amphibole and chlorite schists interlayers, $13=$ drill hole, $14=$ top of the beds, $15=$ contact, $16=$ road. 


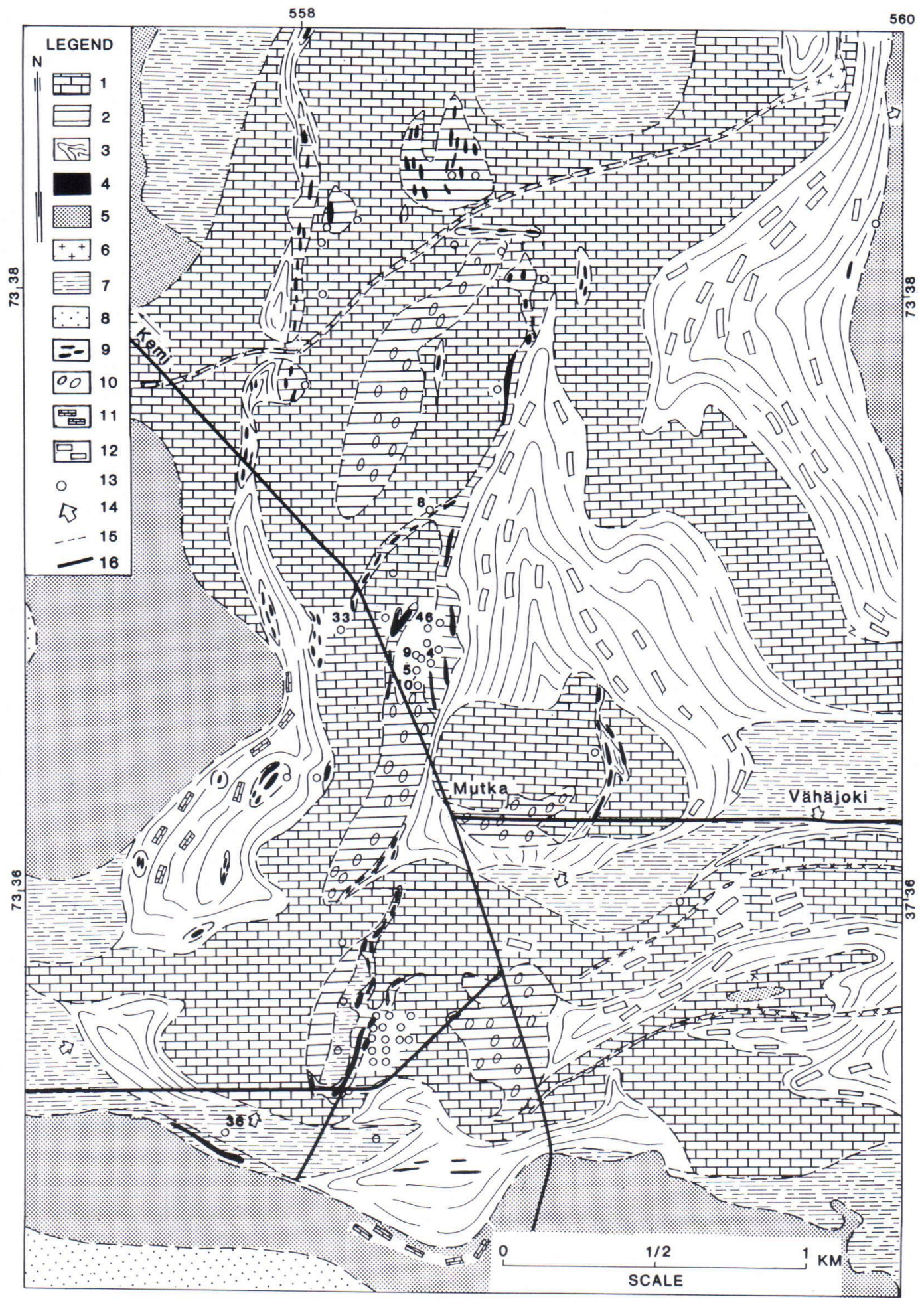


resources of the 14 separate ore bodies amount to 10.5 million tons, but due the fragmentation of the ore bodies, their low metal content and difficulties in concentrating the ore, exploitation is uneconomic (Korvuo 1982).

Mikkola (1947) was the first to describe the geology of the Vähäjoki ores, while later an unpublished Master's thesis was written on them by Vornanen (1963) and further research was done by Lehto in 1975 and 1977.

This article is based on the Master's thesis of the first author (Liipo 1990) in which drill holes numbers $4,5,8,9,10,33,36$ and 46 were studied in detail and additional samples were taken from outcrops at Vähäjoki. 153 electron microprobe analyses and 18 major element and trace element analyses were performed and 106 thin sections were studied.

\section{Petrography of the host rocks and ores}

The area forms part of the Karelian (Early Proterozoic) Peräpohja Schist Belt, which has recently been mapped by Perttunen (1971, 1980, 1983, 1985, 1989). This Belt consists of a quartzitedominated lower supracrustal sequence (»Jatuli») deposited nonconformably on the late Archaean Pudasjärvi granitoid-gneiss complex and overlain by a thick monotonous sequence of metapelites (»Kaleva»). The upper part of the Jatuli contains the Rantamaa Dolomite Formation. The Vähäjoki ores occur in this Formation in the form of veins brecciating the dolomite or disseminations in the chlorite schits and mica schists.

\section{Dolomite}

Dolomite is the main host rock of the iron ores and occurs in thick beds or interbedded with mica schists and amphibole rocks. It is also met with as fragments in the breccias and interbeds in the quartzite. The rock is homogeneous and is mainly composed of dolomite with accessory calcite, quartz, tremolite-actinolite, biotite, talc and chlorite. It is brecciated by calcite veins in some places.

\section{Amphibole rocks and schists}

Amphibole schists are also dominant rocks in the iron ore zone alongside dolomite. There are two main types: actinolite-chlorite schists and actinolite-biotite schists, of which the former is the main one. In some places, the schists are so rich in tremolite-actinolite that they form monomineralic tremolite-actinolite rocks.

The actinolite-chlorite schists are composed of tremolite-actinolite porphyroblasts embedded in a chlorite-rich matrix. Biotite, if present, occurs in the form of porphyroblasts. The actinolitebiotite schists contain small flakes of biotite in the place of chlorite. The main accessory mineral is magnetite, with some cummingtonite, hornblende, quartz, calcite, epidote and allanite.

\section{Chlorite schists and mica schists}

Fine grained chlorite schists and mica schists usually occur as interbeds in the dolomite and with the amphibole rocks and schists. They are composed of variable amounts of chlorite or biotite and quartz with accessory epidote, calcite, tourmaline, feldspar, garnet, sphene and allanite. A specific structural feature of the chlorite schists is the presence of white pebbles, mainly consisting of quartz with accessory biotite and albite.

\section{Breccia}

The breccia forms a north-south trending zone and consists fragments of dolomite, chert, mica schist and magnetite ore stretched parallel to the lineation. The fragments are from rounded to angular in shape and $2-50 \mathrm{~cm}$ across in size.

The dolomite fragments have been altered to calcite-tremolite-actinolite rocks during metamorphism, while the slighty altered fragments (Fig. 3) consist of a dolomite core surrounded by 


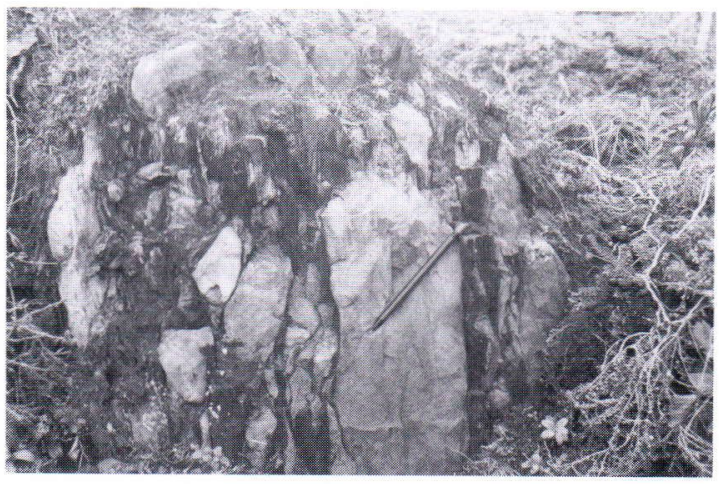

Fig. 3. Breccia in which the dolomite balls have been altered completely. Outcrop group 1 . Scale is $14 \mathrm{~cm}$.

a reaction rim of calcite. Completely altered $\mathrm{Mg}$ rich sediment fragments (Fig. 4) are composed of calcite, biotite, quartz and cummingtonite or only of cummingtonite with accessory magnetite, haematite and quartz. The chert fragments are made up of fine-grained quartz and magnetite with accessory cummingtonite, the mica schist fragments of fine-grained biotite, quartz, calcite and magnetite, which occurs as a dissemination, and the ore fragments mainly of magnetite.

The matrix of the breccias can be divided into two types. The first is composed of a cummingtonite-bearing chlorite schist or cummingtonite rock with euhedral biotite, garnet, magetite, pyrite and chalcopyrite porphyroblasts. In both cases the cummingtonite is altered to hornblende. The second matrix type consists of biotite schist with hornblende and epidote porphyroblasts.

\section{Iron ores}

The iron ores can be divided into two main types, breccia and dissemination ores, the main ore mineral being magnetite in both cases. The breccia ores, met with only in the drill holes, occur mainly in dolomite, whereas the dissemination ores occur in amphibole rocks and schists. There is also a third type termed the E-W ore because, unsually, it trends east-west, which is found just south of the main ore zone (Fig 5).

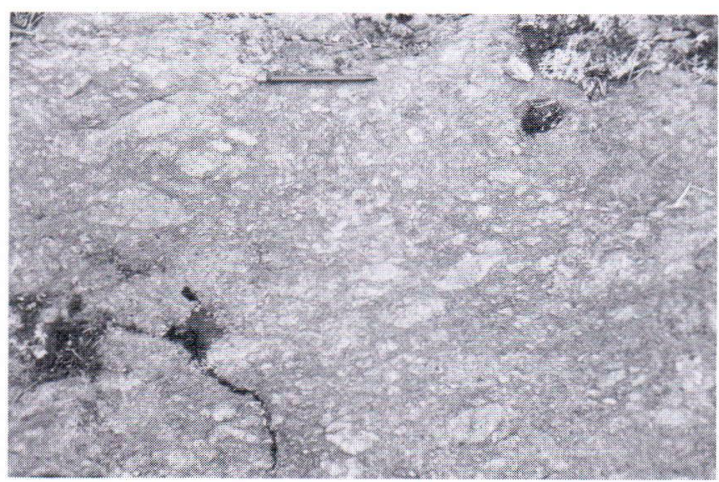

Fig. 4. Breccia in which the balls are slightly altered. Outcrop group 2 . Scale is $14 \mathrm{~cm}$.

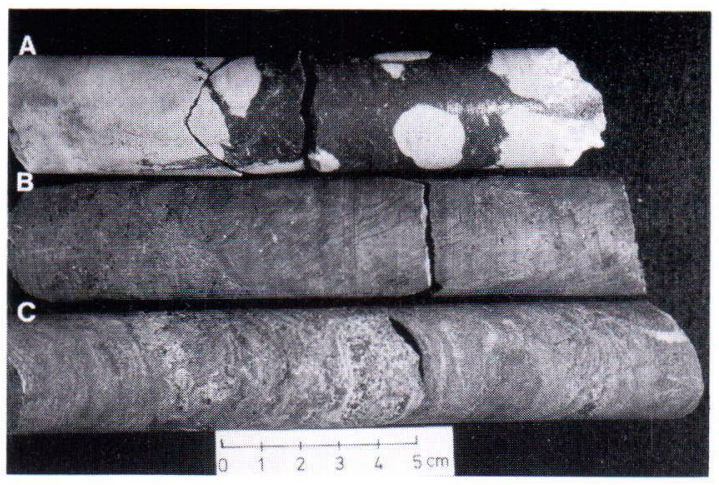

Fig. 5. Iron ore types from Vähäjoki: A) breccia type, B) dissemination type, and C) E-W ore type.

The contacts between the dolomite and the iron ore are sharp, and some of the them present no reaction rims, although dolomite has been altered to calcite at such points.

The degree of brecciation in the breccia type varies from narrow magnetite veins brecciating the host rock to the breccia ore, which contains dolomite fragments in a magnetite matrix. This has been described as a ball texture (Geijer 1971) or durchbewegung texture (Vokes 1969 and 1973), the latter term being widely accepted (Gilligan \& Marshall 1987). The dolomite fragments are either unaltered or have been altered only slightly, possessing a thin outer rim of calcite. The ore material is composed mainly of magne- 
tite with accessory cummingtonite, biotite and tremolite-actinolite.

The typical feature of the dissemination type of ore is that in addition to even dissemination also thin magnetite layers in which the grain size of the magnetite varies from one layer to another occur. The rock is composed of chlorite or biotite, magnetite, cummingtonite and tremoliteactinolite.

In addition to its exeptional trend, the E-W ore differs from the others in occurring in both dolomite and amphibole schists. The most typical variety is a dolomite with magnetite bands. It also stands out from the other ores in possessing greater amounts of chalcopyrite. The E-W ore is composed mainly of magnetite, chalcopyrite, biotite and tremolite-actinolite.

\section{Mineralogy and mineral chemistry}

In order to establish the mineral chemistry and metamorphism of the hosts and ores, $153 \mathrm{elec}$ tron probe microanalyses were analyzed by JEOLJCXA-733 microprobe at the Institute of Electron Optics, University of Oulu. Amphiboles were tabulated and named by means of the AMPHTAB program (Rock 1987). Compositional variations for the minerals are described below. The analyses are presented in full in Liipo (1990).

\section{Carbonates}

The major carbonate mineral is a dolomite which occurs in tiny grains and is largely dolomite or Fe-dolomite. Some dolomite grains are zoned, with their rims richer in iron than the cores. Calcite occurs in distinct grains or veins cutting and brecciating dolomite. Representative carbonate analyses are given in Table 1 .

\section{Amphiboles}

Tremolite-actinolite is the main amphibole in the host rocks, whereas cummingtonite is encountered mostly in the ores and hornblende in the breccia zone (Fig. 6). Representative amphibole analyses are given in Table 2 .

Tremolite-actinolite occurs in elongated grains or porphyroblasts, and its rims may contain hornblende. Tremolite is usually ferri-tremolite. Actinolite is found in composite grains with cummingtonite, the latter always being richer in $\mathrm{Fe}$ than the actinolite (Fig. 7). Actinolite is largely ferri-actinolite or ferrian actinolite.

Cummingtonite occurs in small porphyroblasts, the rims of which have been altered to horn-

Table 1. Representative carbonate analyses. Analyzed at the Institute of Electron Optics, University of Oulu. Sample codes give the drill hole number and the depth in meters.

\begin{tabular}{lrrrrrr}
\hline & 1 & 2 & 3 & 4 & 5 & 6 \\
\hline FEO & 1.64 & 1.23 & 2.09 & 6.96 & 0.39 & 3.14 \\
MNO & 0.33 & 0.35 & 0.22 & 0.50 & 0.23 & 0.47 \\
$\mathrm{MGO}$ & 1.63 & 1.10 & 17.97 & 14.42 & 0.69 & 17.57 \\
$\mathrm{CAO}$ & 53.93 & 51.98 & 28.99 & 27.78 & 55.41 & 28.45 \\
$\mathrm{CO}$ & 42.47 & 45.34 & 50.73 & 50.33 & 43.28 & 50.37 \\
\hline Total & 100.00 & 100.00 & 100.00 & 100.00 & 100.00 & 100.00 \\
$\mathrm{FECO}_{3}$ & 2.6435 & 1.9875 & 3.3673 & 11.222 & 0.6319 & 5.0614 \\
$\mathrm{CACO}_{3}$ & 96.193 & 92.722 & 51.708 & 49.553 & 98.837 & 50.748 \\
$\mathrm{MNCO}_{3}$ & 0.5314 & 0.5605 & 0.3613 & 0.8116 & 0.3661 & 0.7679 \\
$\mathrm{MGCO}_{3}$ & 3.4130 & 2.3032 & 37.551 & 30.144 & 1.4505 & 36.719 \\
\hline
\end{tabular}

$1=10 / 170.00$ Calcite, $2=10 / 170.00$ Calcite, $3=10 / 170.00$ Dolomite, $4=10 / 170.00$ Dolomite, $5=46 / 59.30$ Calcite, $6=46 / 59.30$ Dolomite 
Fig. 6. Classification of Ca amphiboles after Leake (1978). Key: 1 = amphibole schist, 2 = iron ore, 3 = dolomite and $4=$ mica schist. The arrow indicates a change in composition from core to rim. Amphiboles were tabulated by means of the AMPHTAB program (Rock 1987).

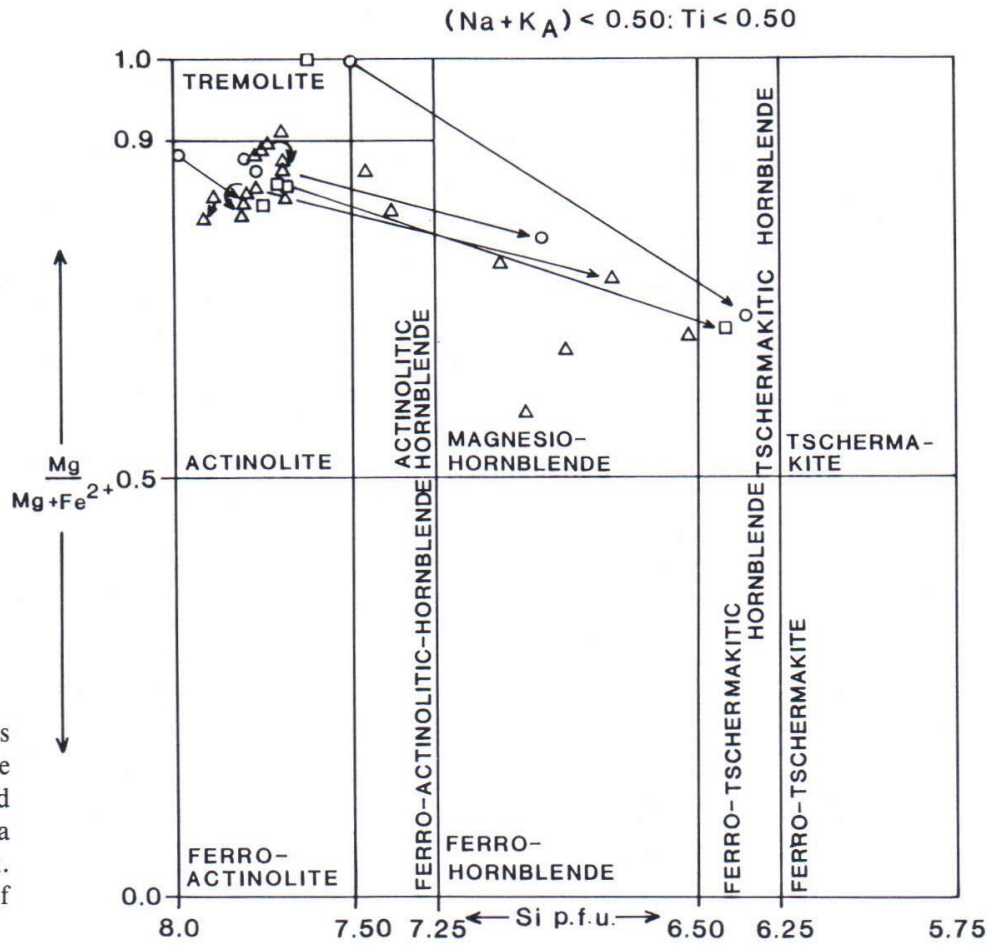

Table 2. Representative amphibole analyses. Explanation: $\mathrm{NAB}=\mathrm{Na} \mathrm{M} 4, \mathrm{NAKA}=\mathrm{Na}^{\mathrm{A}}+\mathrm{K}, \mathrm{ALVI}=\mathrm{Al} \mathrm{VI}^{\mathrm{I}}, \mathrm{MGFE}$ $=\mathrm{Mg} /\left(\mathrm{Mg}+\mathrm{Fe}^{2}\right) \mathrm{CANA}=(\mathrm{Ca}+\mathrm{Na}) \mathrm{B}$. Analyzed at the Institute of Electron Optics, University of Oulu. Amphiboles were tabulated and named by means of the AMPHTAB program (Rock 1987).

\begin{tabular}{|c|c|c|c|c|c|c|}
\hline & 1 & 2 & 3 & 4 & 5 & 6 \\
\hline $\mathrm{SIO}_{2}$ & 58.29 & 53.70 & 54.49 & 43.62 & 47.69 & 55.31 \\
\hline $\mathrm{TIO}_{2}$ & 0.03 & 0.05 & 0.06 & 0.36 & 0.25 & 0.03 \\
\hline $\mathrm{AL}_{2} \mathrm{O}_{3}$ & 0.16 & 2.03 & 1.80 & 12.50 & 9.22 & 0.53 \\
\hline FEO & 7.14 & 11.40 & 10.74 & 14.89 & 11.80 & 19.37 \\
\hline MNO & 0.26 & 0.19 & 0.10 & 0.15 & 0.09 & 0.18 \\
\hline MGO & 19.80 & 16.90 & 16.89 & 10.80 & 13.99 & 19.80 \\
\hline $\mathrm{CAO}$ & 12.45 & 11.56 & 11.39 & 11.90 & 11.82 & 0.61 \\
\hline $\mathrm{NA}_{2} \mathrm{O}$ & 0.04 & 0.22 & 0.22 & 0.66 & 0.72 & 0.04 \\
\hline $\mathrm{K}_{2} \mathrm{O}$ & 0.01 & 0.05 & 0.05 & 0.33 & 0.19 & 0.01 \\
\hline NIO & 0.00 & 0.03 & 0.02 & 0.00 & 0.00 & 0.00 \\
\hline $\mathrm{V}_{2} \mathrm{O}_{3}$ & 0.01 & 0.00 & 0.00 & 0.02 & 0.07 & 0.01 \\
\hline $\mathrm{CR}_{2} \mathrm{O}_{3}$ & 0.00 & 0.01 & 0.00 & 0.00 & 0.00 & 0.00 \\
\hline Total & 98.18 & 96.14 & 95.75 & 95.23 & 95.84 & 95.89 \\
\hline CANA & 1.851 & 1.830 & 1.806 & 2.000 & 2.00 & 0.11 \\
\hline NAB & 0.011 & 0.061 & 0.061 & 0.101 & 0.161 & 0.01 \\
\hline NAKA & 0.002 & 0.009 & 0.009 & 0.152 & 0.076 & 0.00 \\
\hline ALVI & 0.026 & 0.012 & 0.096 & 0.689 & 0.501 & 0.09 \\
\hline MGFE & 0.865 & 0.845 & 0.828 & 0.672 & 0.785 & 0.65 \\
\hline
\end{tabular}

$1=46 / 62.40$ Actinolite, $2=4 / 29.00$ Actinolite, $3=9 / 169.10$ Actinolite, $4=10 / 170.00$ Tschermakite hornblende, 5 $=46 / 146.10$ Magnesio-hornblende, $6=8 / 98.85$ Cummingtonite 


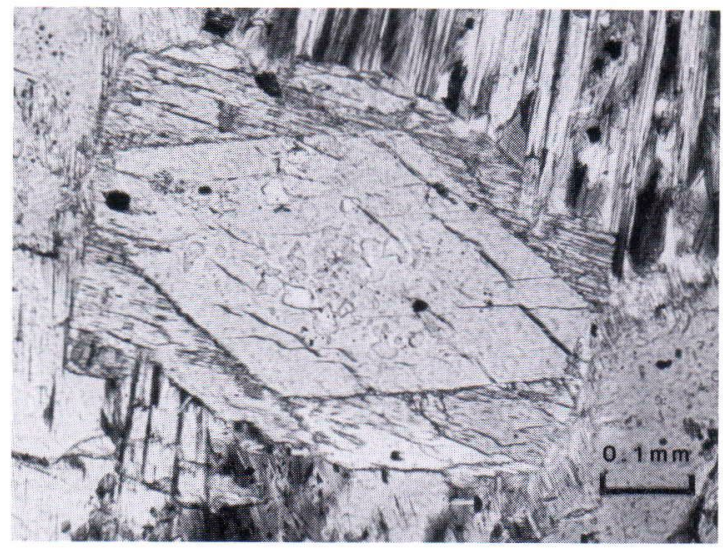

Fig. 7. An actinolite porphyroblast with cummingtonite rim. Sample $9 / 169.10$. Scale is $0.1 \mathrm{~mm}$.

blende. Hornblende occurs in distinct porphyroblasts or as rims to tremolite-actinolite and cummingtonite grains (Fig. 8). Hornblende is usually magnesio-hornblende or tschermakitic hornblende.

This shows that the amphiboles are quite stable in composition, and it is only in the ore and near the magnetite bands that they are richer in iron than elsewhere.

\section{Phyllosilicates}

Biotite occurs in small flakes or porphyroblasts. Two types occur in terms of $\mathrm{Mg} / \mathrm{Fe}$ ratio and colour: green, $\mathrm{Mg}$-rich biotite and brown, Fe-rich biotite which are encountered in dolomites and schists, respectively. The brown biotites have higher $\mathrm{TiO}_{2}$ content $(1.68-3.99 \%$ vs. $0.56-1.68 \%$ ), and this may be the reason for the difference in colour (Robinson et al. 1982). One significant feature of the mineral chemistry of the brown biotites is their high $\mathrm{BaO}$ content $(0.18-$ $7,90 \%)$, the green biotites containing much less $(0.14-0.23 \%)$. Representative biotite and barium analyses are given in Tables 3 and 4, respectively.

Chlorite is one of the main gangue minerals together with the biotite and amphiboles. It occurs in small flakes. Small flakes of talc occur in the dolomite and in shear zones.

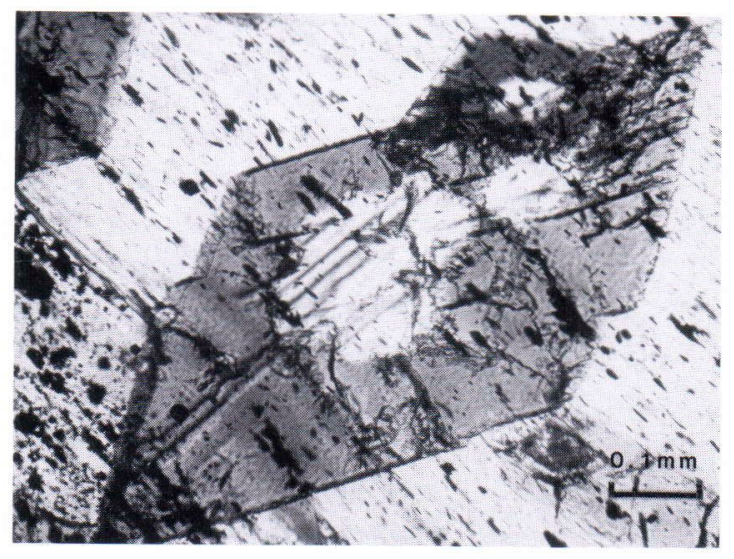

Fig. 8. A hornblende porphyroblast with cummingtonite core. Sample $8-\mathrm{V}-89$. Scale is $0.1 \mathrm{~mm}$.

\section{Feldspars}

The plagioclase in the samples studied is albite $\left(\mathrm{An}_{0}\right)$ and occurs in small grains in the dolomite and in pebbles together with quartz and biotite. The orthoclase is mostly altered to sericite, but in small relicts may occur locally.

\section{Other gangue minerals}

Epidote occurs in idiomorphic or hypidiomorphic porphyroblasts with actinolite and hornblende. Inclusions of metamict allanite occur in some epidote porphyroblasts.

Tourmaline is met with in the form of zoned idiomorphic porphyroblasts, of a composition between the buergerite and dravite end members.

Almandine (alm ${ }_{62.62-80.30}$ ) is a rare mineral at Vähäjoki. It is stretched out tectonically parallel to the lineation in the ore zone and has quartz and magnetite inclusions. Beyond of the iron ore zone it occurs as idiomorphic grains with cummingtonite inclusions. Representative garnet analyses are given in Table 5 .

\section{Ore minerals}

The most common ore mineral is magnetite, typically with great variations in grain size, from $0.01 \mathrm{~mm}$ in disseminated types to $0.3 \mathrm{~mm}$ in porphyroblasts, but mostly in the range $0.01-$ 
Table 3. Representative biotite analyses. Analyzed at the Institute of Electron Optics, University of Oulu.

\begin{tabular}{lrrrrrr}
\hline & 1 & 2 & 3 & 4 & 5 & 6 \\
\hline $\mathrm{SIO}_{2}$ & 40.82 & 39.76 & 32.07 & 30.90 & 31.04 & 33.17 \\
$\mathrm{TIO}_{2}$ & 0.58 & 0.68 & 3.89 & 3.99 & 3.65 & 3.56 \\
$\mathrm{AL}_{2} \mathrm{O}_{3}$ & 13.47 & 14.62 & 16.42 & 15.92 & 16.57 & 15.51 \\
$\mathrm{FEO}$ & 10.15 & 9.99 & 26.18 & 27.18 & 26.97 & 27.07 \\
$\mathrm{MNO}$ & 0.05 & 0.03 & 0.10 & 0.14 & 0.12 & 0.10 \\
$\mathrm{MGO}$ & 19.57 & 18.92 & 4.46 & 3.86 & 3.16 & 4.61 \\
$\mathrm{CAO}$ & 0.18 & 0.01 & 0.01 & 0.01 & 0.04 & 0.08 \\
$\mathrm{NA}{ }_{2} \mathrm{O}$ & 0.54 & 0.61 & 0.09 & 0.06 & 0.10 & 0.06 \\
$\mathrm{~K}_{2} \mathrm{O}$ & 7.00 & 7.82 & 5.54 & 5.09 & 5.58 & 5.82 \\
$\mathrm{NIO}$ & 0.02 & 0.01 & 0.04 & 0.04 & 0.01 & 0.00 \\
$\mathrm{ZNO}$ & 0.00 & 0.00 & 0.00 & 0.00 & 0.00 & 0.00 \\
$\mathrm{~V} \mathrm{O}_{3}$ & 0.05 & 0.04 & .0 .18 & 0.18 & 0.15 & 0.19 \\
$\mathrm{CR}{ }_{2} \mathrm{O}_{3}$ & 0.01 & 0.00 & 0.02 & 0.02 & 0.13 & 0.05 \\
\hline $\mathrm{Total}$ & 92.41 & 92.48 & 89.00 & 87.38 & 87.53 & 90.23 \\
& & & & & & \\
$\mathrm{SI}$ & 6.5630 & 6.4218 & 5.8504 & 5.7879 & 5.8072 & 5.9924 \\
$\mathrm{TI}$ & 0.0703 & 0.0823 & 0.5333 & 0.5615 & 0.5133 & 0.4833 \\
$\mathrm{AL}$ & 2.5521 & 2.7831 & 3.5301 & 3.5144 & 3.6535 & 3.3025 \\
$\mathrm{FE}$ & 1.3646 & 1.3491 & 3.9952 & 4.2576 & 4.2192 & 4.0892 \\
$\mathrm{MN}$ & 0.0063 & 0.0040 & 0.0158 & 0.0222 & 0.0197 & 0.0159 \\
$\mathrm{MG}$ & 4.6891 & 4.5534 & 1.2134 & 1.0785 & 0.8801 & 1.2412 \\
$\mathrm{CA}$ & 0.0310 & 0.0014 & 0.0025 & 0.0030 & 0.0086 & 0.0149 \\
$\mathrm{NA}$ & 0.1677 & 0.1913 & 0.0318 & 0.0214 & 0.0377 & 0.0196 \\
$\mathrm{~K}$ & 1.4350 & 1.6104 & 1.2903 & 1.2155 & 1.3317 & 1.3413 \\
$\mathrm{CR}$ & 0.0009 & 0.0000 & 0.0035 & 0.0025 & 0.0198 & 0.0077 \\
$\mathrm{NI}$ & 0.0023 & 0.0016 & 0.0054 & 0.0060 & 0.0020 & 0.0000 \\
$\mathrm{ZN}$ & 0.0000 & 0.0000 & 0.0000 & 0.0000 & 0.0000 & 0.0000 \\
$\mathrm{~V}$ & 0.0062 & 0.0045 & 0.0257 & 0.0266 & 0.0231 & 0.0278 \\
\hline
\end{tabular}

$1=36 / 97.20,2=36 / 97.20,3=2$-JPL-89, 4 =2-JPL-89, $5=2$-JPL-89, $6=2$-JPL-89.

Table 4. Representative barium analyses from differnt minerals. Analyzed at the Institute of Electron Optics, University of Oulu.

\begin{tabular}{|c|c|c|c|c|c|c|}
\hline & 1 & 2 & 3 & 4 & 5 & 6 \\
\hline $\mathrm{SIO}_{2}$ & - & - & 36.80 & 36.52 & - & 50.74 \\
\hline $\mathrm{TIO}_{2}$ & - & - & 1.07 & 0.85 & - & 0.02 \\
\hline $\mathrm{AL}_{2} \mathrm{O}_{3}$ & - & - & 15.14 & 15.90 & - & 2.04 \\
\hline FEO & 22.84 & 22.08 & 12.58 & 15.85 & 28.53 & 9.31 \\
\hline BAO & 7.90 & 7.21 & 0.39 & 0.23 & 0.04 & 0.02 \\
\hline CL & 0.27 & 0.24 & - & - & 0.01 & - \\
\hline $\mathrm{F}$ & 0.01 & 0.22 & - & - & 0.01 & - \\
\hline $\mathrm{ND}_{2} \mathrm{O}_{3}$ & - & - & 0.15 & 0.06 & - & 0.00 \\
\hline $\mathrm{SM}_{2} \mathrm{O}_{3}$ & - & - & 0.02 & 0.04 & - & 0.09 \\
\hline
\end{tabular}

$1=6.2$-JPL-89 Biotite (brown), $2=6.2-\mathrm{JPL}-89$ Biotite (brown), 36/160.20 Biotite (brown), $4=33 / 123.40$ Biotite (green), $5=6.2$-JPL- 89 Chlorite, $6=46 / 160.20$ Actinolite

$0.05 \mathrm{~mm}$. The small magnetite grains are usually idiomorphic, whereas the magnetite porphyroblasts are rounded and crushed. Some por- phyroblasts have spinel and silicate inclusions or ilmenite exsolution lamellae.

There are at least two generations of magne- 
Table 5. Representative garnet analyses. Analyzed at the Institute of Electron Optics, University of Oulu.

\begin{tabular}{|c|c|c|c|c|c|c|}
\hline & 1 & 2 & 3 & 4 & 5 & 6 \\
\hline $\mathrm{SIO}_{2}$ & 37.72 & 37.50 & 38.85 & 38.63 & 38.76 & 38.40 \\
\hline $\mathrm{TIO}_{2}$ & 0.10 & 0.09 & 0.14 & 0.09 & 0.13 & 0.10 \\
\hline $\mathrm{AL}_{2} \mathrm{O}_{3}$ & 20.94 & 20.90 & 21.36 & 21.16 & 21.33 & 21.16 \\
\hline FEO & 27.35 & 28.17 & 30.90 & 32.16 & 31.86 & 29.26 \\
\hline MNO & 8.41 & 7.14 & 4.47 & 1.42 & 3.99 & 4.99 \\
\hline MGO & 1.26 & 1.35 & 0.75 & 0.89 & 0.72 & 0.51 \\
\hline $\mathrm{CAO}$ & 4.34 & 4.19 & 4.66 & 6.37 & 4.61 & 6.00 \\
\hline $\mathrm{NA}_{2} \mathrm{O}$ & 0.00 & 0.00 & 0.00 & 0.00 & 0.00 & 0.00 \\
\hline $\mathrm{K}_{2} \mathrm{O}$ & 0.00 & 0.00 & 0.00 & 0.00 & 0.00 & 0.00 \\
\hline $\mathrm{NIO}$ & 0.00 & 0.00 & 0.00 & 0.01 & 0.00 & 0.00 \\
\hline ZNO & 0.00 & 0.00 & 0.00 & 0.00 & 0.00 & 0.00 \\
\hline $\mathrm{V}_{2} \mathrm{O}_{3}$ & 0.03 & 0.05 & 0.02 & 0.00 & 0.02 & 0.02 \\
\hline $\mathrm{CR}_{2} \mathrm{O}_{3}$ & 0.03 & 0.01 & 0.02 & 0.04 & 0.01 & 0.00 \\
\hline \multirow[t]{2}{*}{ Total } & 100.20 & 99.41 & 101.16 & 100.78 & 101.44 & 100.44 \\
\hline & \multicolumn{6}{|c|}{ Cations per 24 ogygens } \\
\hline SI & 6.0670 & 6.0696 & 6.1569 & 6.1345 & 6.1405 & 6.1333 \\
\hline TI & 0.0125 & 0.0113 & 0.0161 & 0.0110 & 0.0150 & 0.0124 \\
\hline AL & 3.9697 & 3.9863 & 3.9888 & 3.9610 & 3.9831 & 3.9823 \\
\hline $\mathrm{FE}_{2}$ & 3.6778 & 3.8140 & 4.0945 & 4.2713 & 4.2213 & 3.9085 \\
\hline $\mathrm{MN}$ & 1.1460 & 0.9794 & 0.5997 & 0.1916 & 0.5356 & 0.6751 \\
\hline MG & 0.3025 & 0.3260 & 0.1779 & 0.2119 & 0.1693 & 0.1212 \\
\hline $\mathrm{CA}$ & 0.7471 & 0.7274 & 0.7907 & 1.0837 & 0.7826 & 1.0264 \\
\hline NA & 0.0009 & 0.0000 & 0.0000 & 0.0012 & 0.0000 & 0.0000 \\
\hline K & 0.0000 & 0.0000 & 0.0000 & 0.0000 & 0.0000 & 0.0000 \\
\hline CR & 0.0038 & 0.0019 & 0.0026 & 0.0048 & 0.0010 & 0.0000 \\
\hline NI & 0.0004 & 0.0000 & 0.0000 & 0.0014 & 0.0000 & 0.0000 \\
\hline $\mathrm{ZN}$ & 0.0000 & 0.0000 & 0.0000 & 0.0000 & 0.0000 & 0.0000 \\
\hline V & 0.0044 & 0.0061 & 0.0027 & 0.0000 & 0.0027 & 0.0027 \\
\hline ALM & 62.620 & 65.230 & 72.310 & 74.170 & 73.940 & 68.200 \\
\hline SPE & 19.510 & 16.750 & 10.590 & 3.3300 & 9.3800 & 11.780 \\
\hline GRO & 12.720 & 12.440 & 13.960 & 18.820 & 13.710 & 17.910 \\
\hline PYR & 5.1500 & 5.5800 & 3.1400 & 3.6800 & 2.9700 & 2.1100 \\
\hline
\end{tabular}

$1=10 / 79.25,2=10 / 79.25,3=2$-JPL- $89,4=2$-JPL- $89,5=2$-JPL- $89,6=5$-JPL- 89.

tite, and some grains are zoned, with cores rich in inclusions and purer rims.

Small amounts of ilmenite usually occur in distinct grains, sometimes with haematite, and as exsolution lamellae in the magnetite of the ores the gangue of which is rich in chlorite. Otherwise ilmenite is not a common mineral.

Haematite usually occurs only as an alteration product, but is sometimes encountered with pyrite or in inclusions as pyrite.

Anhedral grains of pyrite, chalcopyrite and pyrrhotite are found filling the spaces between magnetite grains. Cubic pyrite crystals occur randomly in mica-rich zones and in the dolomite, and some pyrite grains have inclusions of chalcopyrite and linneaite. The pyrite contains 44.04 $-44.80 \% \mathrm{FeO}$ and $51.39-52.88 \% \mathrm{~S}$. Some grains are zoned, with a Co-rich rim and a $\mathrm{Co}$ poorer core, but the relation may be reverse in some cases. Arsenopyrite and cobaltite, with small gold inclusions, always occur in idiomorphic grains. 
Table 6. Representative major element and trace elemet analyses. Analyzed by ILPMS at X-Ray Laboratories, Ontario, Canada.

\begin{tabular}{|c|c|c|c|c|c|c|}
\hline & 1 & 2 & 3 & 4 & 5 & 6 \\
\hline \multicolumn{7}{|c|}{ Major elements } \\
\hline $\mathrm{SIO}_{2}$ & 38.30 & 44.60 & 1.82 & 54.20 & 8.26 & 7.17 \\
\hline $\mathrm{TIO}_{2}$ & 1.35 & 0.43 & 0.04 & 1.05 & 0.18 & 0.07 \\
\hline $\mathrm{AL}_{2} \mathrm{O}_{3}$ & 13.20 & 7.03 & 0.37 & 11.80 & 1.42 & 1.62 \\
\hline $\mathrm{FE}_{2} \mathrm{O}_{3}$ & 17.40 & 16.00 & 1.83 & 12.40 & 84.80 & 71.20 \\
\hline MNO & n.d. & n.d. & 0.43 & n.d. & n.d. & 0.11 \\
\hline MGO & 14.60 & 21.10 & 19.90 & 12.70 & 3.67 & 7.63 \\
\hline $\mathrm{CAO}$ & 2.30 & 1.99 & 30.10 & 0.41 & 0.77 & 5.12 \\
\hline $\mathrm{NA}_{2} \mathrm{O}$ & 0.35 & 0.08 & 0.17 & 0.02 & 0.10 & 0.09 \\
\hline $\mathrm{K}_{2} \mathrm{O}$ & 6.83 & 0.02 & 0.03 & 0.19 & 0.21 & 0.02 \\
\hline $\mathrm{P}_{2} \mathrm{O}_{5}$ & 0.12 & 0.16 & 0.09 & 0.08 & 0.05 & 0.19 \\
\hline LOI & 1.00 & 6.00 & 44.90 & 7.08 & -1.00 & 5.77 \\
\hline TOT & 96.00 & 97.40 & 99.70 & 100.00 & 98.50 & 99.00 \\
\hline \multicolumn{7}{|c|}{ Trace elements } \\
\hline $\mathrm{AU}$ & $<1$ & 2 & $<1$ & $<1$ & 2 & $54 \mathrm{ppb}$ \\
\hline $\mathrm{CU}$ & 56.0 & $<0.5$ & 1.0 & 54.0 & 2.0 & 1700 ppm \\
\hline $\mathrm{ZN}$ & 98.0 & 130 & 14.0 & 340 & 220 & 110 \\
\hline $\mathrm{S}$ & 180 & $<100$ & 140 & $<100$ & 740 & 6000 \\
\hline V & 290 & 40 & 20 & 250 & 80 & 50 \\
\hline $\mathrm{CR}$ & 120 & $<2$ & $<2$ & 120 & $<2$ & $<2$ \\
\hline MN & 390 & 340 & n.d. & 440 & 140 & n.d. \\
\hline $\mathrm{CO}$ & 65 & 16 & 4 & 32 & 95 & 188 \\
\hline NI & 100 & 84 & 8 & 94 & 1 & 4 \\
\hline AS & 2 & 3 & 1 & 3 & 6 & 43 \\
\hline MO & 4 & $<2$ & 2 & 4 & $<2$ & $<2$ \\
\hline RB & 201 & 21 & 15 & 20 & $<10$ & $<10$ \\
\hline SR & $<10$ & $<10$ & $<10$ & $<10$ & $<10$ & $<10$ \\
\hline $\mathrm{Y}$ & $<10$ & 13 & $<10$ & $<10$ & $<10$ & $<10$ \\
\hline ZR & 63 & 50 & $<10$ & 29 & $<10$ & $<10$ \\
\hline NB & 15 & 22 & 22 & 28 & 31 & $<10$ \\
\hline BA & 5040 & 97 & $<10$ & 170 & 606 & 155 \\
\hline TA & $<1$ & 1 & $<1$ & $<1$ & $<1$ & $<1$ \\
\hline PB & $<2$ & $<2$ & $<2$ & $<2$ & 6 & 30 \\
\hline TH & $<1$ & 2.5 & $<1$ & $<1$ & $<1$ & 2.8 \\
\hline U & 1.2 & 0.7 & $<0.5$ & $<0.5$ & $<0.5$ & 5.6 \\
\hline
\end{tabular}

$1=46 / 160.20$ Actinolite-biotite schist

$2=33 / 63.50$ Actinolite rock

$3=36 / 26.95$ Dolomite

$4=36 / 11.20$ Mica schist

$5=33 / 76.90$ Ore

$6=36 / 90.00$ Ore

\section{Whole rock chemistry}

18 major element and trace element analyses for the drill holes numbers 33, 36 and 46 were performed by X-Ray-Assay Laboratories, Ontario, Canada, and previous analyses by the Rautaruukki and Outokumpu companies were also available. Representative analyses are given in Table 6, and full data in Liipo (1990).

\section{Dolomite}

The dolomites contain 23.91-53.50\% $\mathrm{CaO}$ and $3.20-19.90 \% \mathrm{MgO}$, and their $\mathrm{CaO} / \mathrm{MgO}$ 
ratios range from 1.4 to 16.7 , although in most cases the figure is $1.5-1.6$. These ratios indicate that the rocks are dolomite or slightly calcian dolomite (Frolova 1959).

\section{Amphibole rocks and schists}

In spite of some differences in the amouts of quartz and iron oxides, the amphibole rocks and schists are chemically very similar. They contain 24.05-48.73\% $\mathrm{SiO}_{2}, 8.54-39.90 \% \mathrm{Fe}_{2} \mathrm{O}_{3}$ and $13.40-26.50 \% \mathrm{Fe}^{\text {tot }}$, the variations being due to flunctuations in the amouts of magnetite and pyrite. $\mathrm{MgO}$ and $\mathrm{MnO}$ contents are between $7.70-21.10 \%$ and $0.03-0.48 \%$, respectively, again due to the variations in the proportions of tremolite-actinolite, biotite and chlorite. The highest $\mathrm{MgO}$ concentrations are found in the tremolite-actinolite rocks and the lowest in the amphibole schists. Trace element concentrations are generally low, the amphibole rocks and schists containing $<0.5-630.0 \mathrm{ppm} \mathrm{Cu}, 37.0-$ $760 \mathrm{ppm} \mathrm{Zn},<100-940 \mathrm{ppm} \mathrm{S}$ and $4-222 \mathrm{ppm}$ Co. Ba varies in the range $81.0-5040 \mathrm{ppm}$, being highest in the rocks rich in Ba-bearing biotite.

\section{Chlorite and mica schists}

The chlorite and mica schists are highly consistent in their main element concentrations, which also resemble those of the amphibole rocks and schists containing 22.00-61.73\% $\quad \mathrm{SiO}_{2}$, 5.08-29.20 $\mathrm{Fe}_{2} \mathrm{O}_{3}, 13.50-20.90 \% \mathrm{Fe}^{\mathrm{tot}}, 4.60-$ $15.20 \% \mathrm{MgO}$ and $0.02-14.30 \% \mathrm{MnO} . \mathrm{Cu}$ is in the range $<0.5-340 \mathrm{ppm}, \mathrm{Zn} 24.0-1100 \mathrm{ppm}$, $\mathrm{S}<100-360 \mathrm{ppm}$, Mo $<2.0-156 \mathrm{ppm}$ and $\mathrm{Ba}$ $170.0-4120 \mathrm{ppm}$.

\section{Iron ore}

The average composition of the Vähäjoki iron ores is $39.4 \% \mathrm{Fe}^{\text {tot }}, 0.07 \% \mathrm{P}_{2} \mathrm{O}_{5}, 14100 \mathrm{ppm} \mathrm{S}$, 1670 ppm Cu, 290 ppm Co and 0.1-0.6 ppm Au (Korvuo 1982). The analyses made by Lapin Malmi indicate a $\mathrm{SiO}_{2}$ content of 7.17-42.95\%, $\mathrm{Al}_{2} \mathrm{O}_{3} \quad 0.42-11.28 \%$ and $\mathrm{P}_{2} \mathrm{O}_{5} \quad 0.05-3,84 \%$.
$\mathrm{P}_{2} \mathrm{O}_{5}$ concentrations in the ores are usually below $0.1 \%$, but a substantially higher figure of $3.48 \%$ is recorded in the E-W ore body which is cut by drill hole number 36 . The dolomite with martite bands found in the same drill hole, also has a relatively high $\mathrm{P}_{2} \mathrm{O}_{5}$ content $(1.3 \%)$ near its contact with the quartzite (Korvuo 1982).

The analyses of iron ores carried out here show them to contain 71.20-84.80\% $\quad \mathrm{Fe}_{2} \mathrm{O}_{3}$, 7.17-8.26\% $\mathrm{SiO}_{2}, 0.07-1.42 \% \mathrm{Al}_{2} \mathrm{O}_{3}$ and 0.05 $-0.19 \% \mathrm{P}_{2} \mathrm{O}_{5}$, together with $2-1700 \mathrm{ppm} \mathrm{Cu}$, $110-220$ ppm Zn , 740-6000 ppm S, 95-188 ppm Co and 155-606 ppm Ba (Table 2).

\section{Metamorphism}

The medium pressure epidote-amphibolite facies is characterized by an albite + epidote + hornblende assemblage in metabasites. Since actinolite occurs in the greenschist facies metabasites and coexists with hornblende in the transitional zone with the epidote-amphibolite facies, the boundary between the greenschist and epidote-amphibolite facies lies at the temperature where the dominant calcic amphibole changes from actinolite to hornblende (Miyashiro 1978, Maruyama et al. 1983).

This change takes place under approximately the same $\mathrm{P}, \mathrm{T}$ conditions as mark the appearence of almandine-garnet in the metapelitic rocks, i.e. at about $500{ }^{\circ} \mathrm{C}$ at medium and high pressures, and the temperature rises only slightly with increasing pressure. The appearance of almandine is related to the $\mathrm{Fe} /(\mathrm{Fe}+\mathrm{Mg})$ ratio in the rocks, so that it appears first within a narrow P-T zone. The first appearance of cummingtonite-grynerite amphiboles takes place at about $450-500{ }^{\circ} \mathrm{C}$ if the pressure is between 2 and $5 \mathrm{Kbar}$.

Whether the cummingtonite forms composite grains with actinolite or hornblende depends on the chemistry of the rock and the grade of metamorphism. Cummingtonite-actinolite pairs have been encountered in the rocks varying from an epidote-amphibolite facies to granulite facies. 
Table 7. Representative metamorphic temperatures obtained using the formulas of Perchuk et al. (1981) T1, Ferry \& Spear (1978) T2, Pigage \& Greenwood (1982) T3, Hodges \& Spear (1982) T4, Perchuk \& Lavernt'eva (1983) T5, Sheppard \& Schwartz (1970) T6, Bickle and Powell (1977) T7, and Annovitz \& Essene (1987) T8. Temperatures are given as ${ }^{\circ} \mathrm{C}$. Samples $1-6$ are from breccia and samples $7-11$ are from dolomite.

\begin{tabular}{|c|c|c|c|c|c|c|}
\hline \multicolumn{7}{|c|}{ garnet-biotite: } \\
\hline & 1 & 2 & 3 & 4 & 5 & 6 \\
\hline $\mathrm{T} 1$ & 631 & 496 & 507 & 552 & 541 & 521 \\
\hline $\mathrm{T} 2$ & 686 & 485 & 504 & 584 & 559 & 511 \\
\hline T3 & 840 & 606 & 636 & 761 & 700 & 624 \\
\hline $\mathrm{T} 4$ & 760 & 536 & 556 & 654 & 613 & 563 \\
\hline T5 & 374 & 543 & 527 & 467 & 481 & 508 \\
\hline
\end{tabular}

calcite-dolomite:

\begin{tabular}{lllllr} 
& 7 & 8 & 9 & 10 & 11 \\
\hline T6 & 473 & 388 & 468 & 539 & - \\
T7 & 481 & 416 & 477 & 531 & 315 \\
T8 & 504 & 454 & 496 & 543 & 329 \\
\hline
\end{tabular}

The $\mathrm{Fe} /(\mathrm{Fe}+\mathrm{Mg})$ ratio in cummingtonite is usually higher than in the coexisting $\mathrm{Ca}$ amphibole (Laird \& Albee 1981).

The chemical compositions of amphiboles provide valuable information on the metamorphic conditions under which they were formed. Tremolite molecules characteristically dominates the amphibole chemistry in greenschists, glaucophane molecules in blueschists, tschermakite molecules in amphibolites and edenite molecules in albite-epidote-amphibolites. The zonation and overgrowth in amphiboles record the evolution of metamorphic conditions in the rocks in question (Holland \& Richardson 1979).

The occurrence of tremolite-actinolite at Vähäjoki marks the first increase in temperature. The appearance of cummingtonite may also be related to this event, but occurs later. The hornblende rimming the tremolite-actinolite and cummingtonite then corresponds to the last increase in temperature, when the metamorphic facies changed from greenschist to epidote-amphibole.

\section{Temperature}

Six garnet-biotite pairs were analyzed in three samples from breccia. The temperatures obtained using the formulas of Perchuk et al. (1981), 496-631 ${ }^{\circ} \mathrm{C}$, and Ferry \& Spear (1978), 482$681^{\circ} \mathrm{C}$, are less variable than those following $\mathrm{Pi}-$ gage \& Greenwood (1982), 603-836 ${ }^{\circ} \mathrm{C}$, or Hodges \& Spear (1982), $533-756^{\circ} \mathrm{C}$. The formula proposed by Perchuk \& Lavernt'eva (1983), $374-543{ }^{\circ} \mathrm{C}$, gives the most accurate results (cf. Chipera \& Perkins 1988).

Ten calcite-dolomite pairs were analyzed, but some of them give temperatures that are too low $\left(\mathrm{T}<300{ }^{\circ} \mathrm{C}\right)$. The temperatures obtained using the formulas of Sheppard \& Schwartz (1970), 468-539 ${ }^{\circ} \mathrm{C}$, and Bickle and Powell (1977), $477-531{ }^{\circ} \mathrm{C}$, do not differ very much from those of Annovitz \& Essene (1987), 496-543 ${ }^{\circ} \mathrm{C}$. These temperatures are lower than those obtained by means of garnet-biotite geothermometers, though the mean values do not differ very much (Table 7).

Actinolites with $\mathrm{Fe}: \mathrm{Mg}=1$, if coexisting with cummingtonites, are useful geothermometers and may be used to estimate, or place lower limits on, temperatures of metamorphism with a minimum error of $+/-35^{\circ} \mathrm{C}$ (Cameron 1975). The calcic amphibole at Vähäjoki has a composition of 25-30 mole percent of actinolite, which suggests an equilibration temperature of $500{ }^{\circ} \mathrm{C}$.

The mineral assemblage dolomite + actinolite 


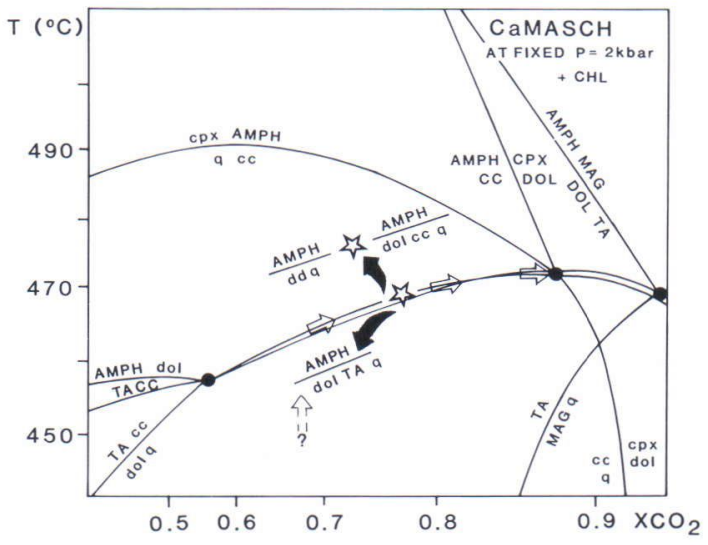

Fig. 9. $\mathrm{T}-\mathrm{X}_{\mathrm{CO} 2}$ petrogenetic grid for the system $\mathrm{CaO}-\mathrm{FeO}-$ $\mathrm{MgO}-\mathrm{Al}_{2} \mathrm{O}_{3}-\mathrm{SiO}_{2}-\mathrm{CO}_{2}-\mathrm{H}_{2} \mathrm{O}$ at 2 kbar projected from chlorite and $\mathrm{CO}_{2}-\mathrm{H}_{2} \mathrm{O}$ fluid. Key: amph = amphibole, $c h l=$ chlorite, $t a=$ talc, $c p x=$ clinopyroxene, $d o l=$ dolomite, $c c=$ calcite, $q=$ quartz, magn = magnesite. Petrogenetic grid after Will et al. (1990). The arrows indicates the $\mathrm{T}-\mathrm{X}_{\mathrm{CO} 2}$ path of the Vähäjoki dolomite.

+ chlorite + talc + calcite + quartz in the dolomite (Fig. 9), points to a lower temperature $\left(475^{\circ} \mathrm{C}\right)$ than those obtained by garnet-biotite geothermometers, but is equal to those temperatures obtained by calcite-dolomite geothermometers. The $\mathrm{X}_{\mathrm{CO} 2}$ of the fluid in the dolomites during the metamorphism was about 0.86 .

\section{Pressure}

Compositions of the $\mathrm{Ca}$ amphiboles can be used to estimate the pressure at metamorphism (Raase 1974, Brown 1977 and Laird \& Albee 1981). Plotting of the Ca amphiboles from Vähäjoki on the $\mathrm{Na} \mathrm{M} 4-\mathrm{Al}^{\mathrm{VI}}$ diagram of Brown (1977) suggests a metamorphic pressure of 2-3 Kbar, whereas the diagram of Laird and Albee (1981) denotes medium or high pressure conditions (Fig.10).

The compositions of $\mathrm{Ca}$ amphiboles and the temperatures obtained from the garnet-biotite and calcite-dolomite geothermometers suggest that the temperature during metamorphism was about $465^{\circ} \mathrm{C}$ and the pressure about $2-4 \mathrm{Kbar}$. These estimates correspond well to the those reached in other parts of the Peräpohja schist area (Salonsaari 1990).

\section{Remobilization}

Remobilization is a process of regeneration of new ore bodies from pre-existing ores during a younger orogenic period with or without contemporaneous intrusion and subsequent volcanism, implying participation of fluid agencies, volcanic or metamorphic (Mookherjee 1976). There is evidence that deformation processes in low to medium-grade metamorphic terrains have been controlled by aqueous mass transport mechanisms operating in conjuction with dissolution and precipitation processes (Cox et al. 1986). Different types of mobilization can be classified as chemical, including solution, diffusion and volatile transport; transitional, including partial melting and solution; or physical, including plastic flowage and melting (Mookherjee 1976). The metamorphic conditions assosiated with remobilization are different from those of deposition (Hobbs 1987).

The Vähäjoki iron ores belong to the class of polymetamorphic skarn iron deposits. These ores are considered to be iron-silica-carbonate-rich sediments which have attained their present mineral composition through later metamorphic processes (Zitzmann \& Neumann-Redlin 1977). Skarn is used here as a term for lime-bearing silicates derived from nearly pure limestone and dolomite with the introduction of large amounts of $\mathrm{Si}, \mathrm{Al}, \mathrm{Fe}$ and $\mathrm{Mg}$ (Bates \& Jackson 1987).

Mikkola (1947) explains that skarn building reactions and contact metasomatic changes took place between phyllite and dolomite and transported material into the ore zone, where conditions were favourable for the formation of magnetite, and the iron was stored there. Vornanen (1963) is of opinion that the magnetite ore and the sulphides are heterogenetic, the magne- 

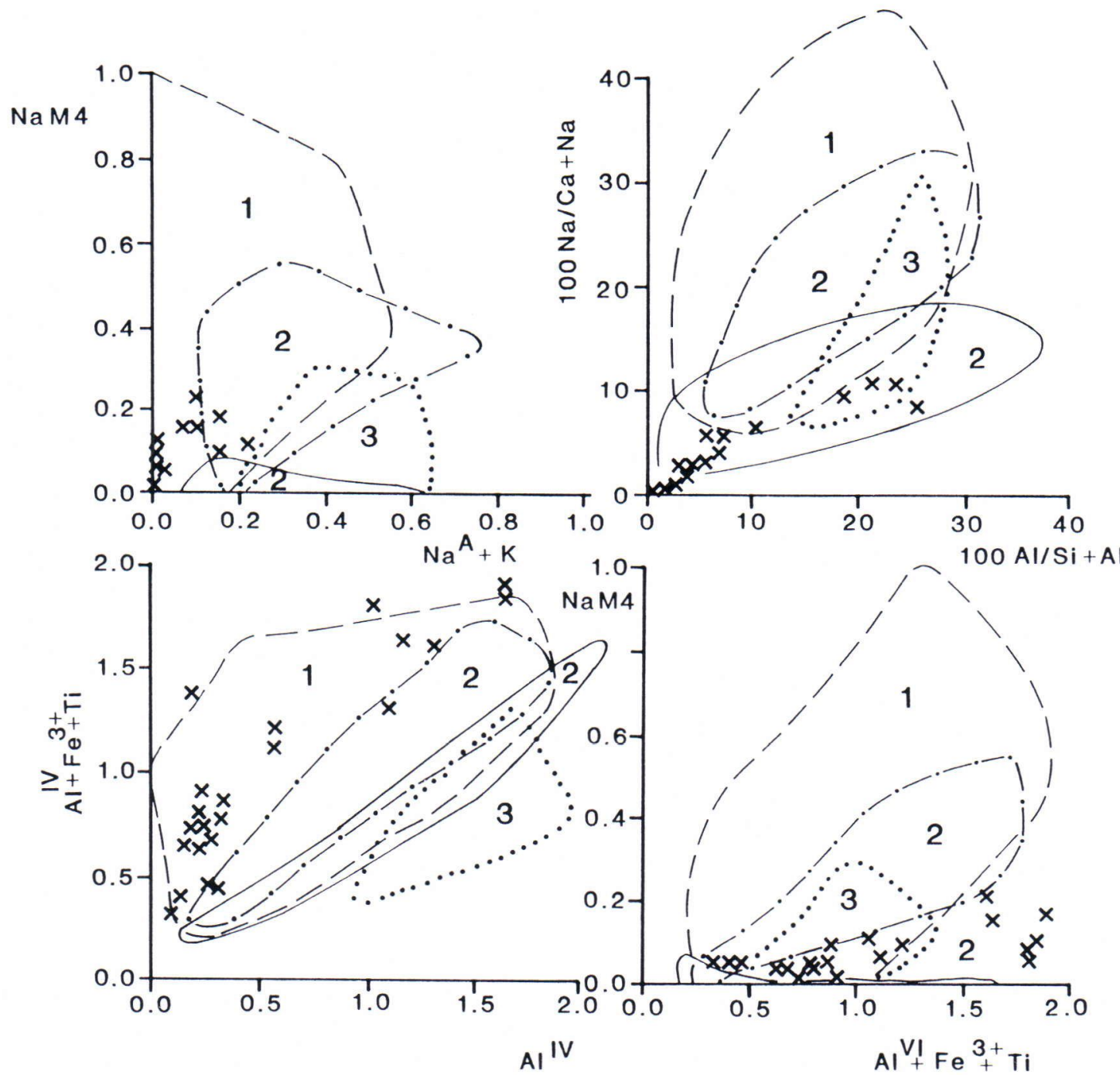

Fig. 10. Ca amphiboles from Vähäjoki placed on the diagram of Laird \& Albee (1981). Key: 1 = high pressure field, $2=$ medium pressure field and $3=$ low pressure field. Amphiboles were tabulated by means of the AMPHTAB program (Rock 1987).

tite being of sedimentary origin and the sulphides are related to the magmatic rocks. Lehto (1975) suspects that the ores went through several skarn building and mobilisation stages.

Skarn building reactions took place within a specific bed without any reactions between the bed and the enclosing rocks indicate that there was a free fluid phase during the metamorphism.
The fluids carrying the ore material are thought to have been metamorphic, because the ores are not directly connected with volcanites but occur in dolomites and there are no intrusives in the area. The north-south breccia zone in which the ores and amphibole schists are located acted as a channel for the fluids carrying the ore material. The focusing of fluid flow in high-perme- 
ability fault zones or shear zones may locally enhance rates of dissolution and remobilization (Cox et al. 1986).

During the early stages of metamorphism preexisting iron ores were remobilized partly physically and partly chemically, the durchbewegung textures of the breccia ores being caused by plastic flowage. The fluid flow was focussed in the $\mathrm{N}-\mathrm{S}$ zone, where the ores were formed.

\section{Conclusions}

The Vähäjoki iron ores occupy the uppermost part of the Karelian (Early Proterozoic) quartzitedolomite sequence deposited on the late Archaean basement in southern Lapland. The ores occur as magnetite veins brecciating dolomite and as magnetite disseminations in chlorite and mica schists.

The only main ore mineral is magnetite, with which there occur accessory ilmenite, haematite, pyrite, chalcopyrite, pyrrhotite, arsenopyrite and cobaltite with small gold inclusions. The main gangue minerals are dolomite or Fe-dolomite in the dolomites, ferri-tremolite, tremolite, ferri-

\section{References}

Anovitz, L. \& Essene, E., 1987. Phase equilibria in the system $\mathrm{CaCO}_{3}-\mathrm{MgCO}_{3}-\mathrm{FeCO}_{3}$, J. Petrol. 28, 389-414.

Bates, R. \& Jackson, J., 1987. Glossary of Geology, Third Edition. American Geological Institute. 788 p.

Bickle, M. \& Powell, R., 1977. Calcite-dolomite geothermometry for iron-bearing carbonates. Contrib. Mineral. Petrol. 59, 281-292.

Brown, E., 1977. The crossite content of Ca-amphibole as a guide to pressure of metamorphism, J. Petrol. 18, $53-72$.

Cameron, K., 1975. An experimental study of actinolitecummingtonite phase relations with notes on the syntesis of Fe-rich anthophyllite. Am. Mineral. 60, 375-390.

Chipera, S. \& Perkins, D., 1988. Evalution of biotite-garnet geothermometers: application to the English River subprovince, Ontario. Contrib. Minral. Petrol. 98, 40-48.

Cox, S.; Etheridge, M. \& Wall, V., 1986. The role of fluids actinolite and ferrian actinolite, cummingtonite, magnesio-hornblende and tschermakitic hornblende in amphibole-bearing hosts, green Mg-rich biotite, brown $\mathrm{Fe}$-rich biotite and $\mathrm{Ba}$-bearing biotite, and chlorite in chlorite and mica schists.

The garnet-biotite and calcite-dolomite geothermometers and the mineral chemistry of the $\mathrm{Ca}$ amphiboles suggest that the Vähäjoki iron ores were metamorphosed under greenschist - amphibolite facies conditions ( $\mathrm{T}=465^{\circ} \mathrm{C}$ and $\mathrm{P}$ $=2-4 \mathrm{Kbar})$. The $\mathrm{X}_{\mathrm{CO} 2}$ of the fluid in the dolomites during the metamorphism was about 0.86 . An increase in metamorphic grade is reflected in the change in amphibole composition from tremolite-actinolite to tschermakitic hornblende.

During the early stages of metamorphism preexisting iron ores were remobilized partly physically and partly chemically, the durchbewegung textures of the breccia ores being caused by plastic flowage.

Acknowledgements. Useful discussions have been held on this subject with FT P. Tuisku. The English of the manuscript was corrected by Malcolm Hicks, M.A., and the figures were drawn by Mrs. Kristiina Karjalainen. We are deeply grateful to all these people.

in syntectonical mass transport and localization of metamorphic vein-type ore deposits. Ore Geol. Rev. 2, 65-86.

Deer, W.; Howie, R. \& Zussman, J., 1967. Rock-forming Minerals. 5th imp, Longman London and New York.

Ferry, J. \& Spear, F., 1978. Experimental calibration of the partitioning of $\mathrm{Fe}$ and $\mathrm{Mg}$ between biotite and garnet, Contrib. Mineral. Petrol. 66, 113-117.

Frolova, E., 1959. On classification of carbonate rocks of limestone-dolomite magnesite series, Nov. Neft. Tecten.,Geol. 3, 34-35.

Geijer, P., 1971. Sulfidic »ball ores» and the pebble dykes. Sver. Geol. Unders. Ser. C, 662, 1-29.

Gilligan, L. \& Marshall, B., 1987. Textural evidence for remobilization in metamorphic environments, Ore Geol. Rev. 2, 205-229.

Hobbs, B., 1987. Principles involved in mobilization and remobilization. Ore Geol. Rev. 3, 37-45.

Hodges, K. \& Spear, F., 1982. Geothermometry, geobarometry and the $\mathrm{Al}_{2} \mathrm{SiO}_{5}$ triple point at Mt. Moosilauke, 
New Hampshire. Am. Mineral. 67, 1118-1134.

Holland, T. \& Richardson, S., 1979. Amphibole zonation in metabasites as a guide to the evolution of metamorphic conditions. Contrib. Mineral. Petrol. 70, 143-148.

Korvuo, E., 1982. Vähäjoen rautamalmialueen tutkimukset 1979-1982. Unpublished report n.o 2/82, Lapin Malmi, $48 \mathrm{p}$.

Laird, B. \& Albee, A., 1981. Pressure, temperature, and time indicators in mafic schist: their application to reconstructing the polymetamorphic history of Vermont. Am. J. Sci. 281, 127-175.

Liipo, J., 1990. Vähäjoen rautamalmien mineralogia ja metamorfoosi. Res Terrae Ser. C. No 14. 62 p.

Lehto, T., 1975. Pohjois-Suomen rautamuodostumat; Raportti Lapin rautamalmien horisonttisidonnaisuusprojektin tutkimuksista Pohjois-Suomessa vuosina 1972-1975. Åbo Akademi, Pohjois-Suomen malmigeologinen toimikunta, Kauppa- ja Teollisuusministeriö. 241 p.

Lehto, T.,\& Niiniskorpi, V., 1977. Pohjois- ja Itä-Suomen rautamuodostumat. Summary: The iron formations of northern and eastern Finland. Geol. Surv. Finland. Report of Investigation, 22. 49 p.

Marayama, S.; Suzuki, K. \& Liou, J., 1983. Greenschist amphibolite transition equilibria at low pressures. J. Petrol. 24, 583-604.

Mikkola, A., 1947. The Vähäjoki iron ore in Tervola, Northern Finland. Bull. Comm. géol. de Finlande. 140, 261 -280 .

Miyashiro, A., 1979. Metamorphism and Metamorphic Belts. 4th ed., George Allen \& Unwin, 492 p.

Mookherjee, A., 1976. Ores and metamorphism: temporal and genetic relations. Wolf, K. (ed.): The handbook of stratabound and stratiform ore deposits, Vol. 4, Tectonics and Metamorphism.

Perchuk, L.; Podlesskii, K. \& Aranovich, L., 1981. Calculation of thermodynamic propertiess of end-member minerals from natural parageneses. p. 111-129 in Newton, R., Narvotsky, A. \& Wood, B. (eds.): Termodynamics of Minerals and Melts. New York, Springer Verlag.

—, \& Lavert'eva, I., 1983. Exprimental investigation of exchange equilibria in the system cordierite-garnet-biotite. p. 199-239 in Saxena, S. (ed.) Kinetics and Equilibrium in Mineral Reactions. Springer, Berlin Heidelberg New York.

Perttunen, V., 1971. Suomen geologinen kartta 1 : 100000. Geologiçal map of Finland. Kallioperäkartta. Pre-Quaternary rocks. Lehti-Sheet 2544, Runkaus. Geol. Surv. Finland.

—, 1980. Stratigraphy of the Peräpohja schist area. A.Silvennoinen (ed.): Jatulian geology in the eastern part of the Baltic shield. Proceedings of a Finnis-Soviet symposion held in Finland 21st-26th August, 1979.
—, 1983. Peräpohjan eteläosan geologia. Unpublished Lisenciate Thesis, Geol. Surv. Finland, K/1983/2. 36 p.

,- 1985 . On the Proterozoic stratigraphy and exogenic evolution of the Peräpohja area,Finland. Pp. 131-142 in K.Laajoki and J.Paakkola (ed.): Proterozoic Exogenic Processes and Related Metallogeny. Proceedings of the symposium held in Oulu, Finland August 15-16,1983. Geol. Survey Finland, Bull. 331.

-, 1989. Peräpohjan vulkaniittitutkimukset. Pp. 67-70 in Manninen, T. (toim.) Tulivuorenkivet Kolarista Kuusamoon. Lapin Vulkaniittiprojektin ekskursio ja esitelmäseminaari 5-10.6.1989. Geol. Surv. Finland, guide 23,

Pigage, L. \& Greenwood, H., 1982. Internally consistent estimates of pressure and temperature: The staurolite problem. Am. J. Sci. 282, 943-969.

Raase, P., 1974. Al and Ti contents of hornblende, indicators of pressure and temperature of regional metamorphism. Contrib. Mineral. Petrol. 45, 231-236.

Robinson, P.; Spear, F.; Schumacher, J.; Laird, J.; Klein, C.; Ewans, B. \& Doolan, B., 1982. Phase relation of metamorphic amphiboles: Natural occurence and theory. Rev. Mineral. 9B, 1-211.

Rock, N., 1987. A fortran program for tabulating and naming amphibole analyses according to the international mineralogical assosiation scheme. Mineral. Petrol. 37, $79-88$.

Salonsaari, P., 1990. Vanttauskosken alueen kallioperän deformaatio. Unpublished Master's thesis. University of Oulu, Department of geology, $62 \mathrm{p}$.

Sheppard, S. \& Schwartz, H., 1970. Fractination of carbon and magnesium between coexisting metamorphic calcite and dolomite. Contrib. Mineral. Petrol. 26, 161-198.

Vokes, F., 1969. A rewiew of the metamorphism of sulfide deposits. Earth-Sci. Rev. 5. 99-143.

-, 1973. "Ball texture» in sulphide ores. Geol. Fören. Stockholm Förh. 95. 403-406

Vornanen, E., 1963. Vähäjoen malmin ja sen lähiympäristön kivilajien geologiaa. Unpublished Master's thesis. University of Helsinki, Department of geology and Mineralogy, $84 \mathrm{p}$.

Will, T.; Powell, R. \& Holland, T., 1990. A calculated petrogenetic grid for ultramafic rocks in the system $\mathrm{CaO}$ $\mathrm{FeO}-\mathrm{MgO}-\mathrm{Al}_{2} \mathrm{O}_{3}-\mathrm{SiO}_{2}-\mathrm{CO}_{2}-\mathrm{H}_{2} \mathrm{O}$ at low pressures. Contrib. Mineral. Petrol. 105, 347-358.

Zitzmann, A. \& Neumann-Redlin, Chr., 1977. The genetic Types of Iron Ore Deposits in Europe and adjacent Areas. Pp. 13-35 in Zitzmann, A. (ed.). The Iron Ore Deposits of Europe and adjacent Areas. Vol. 1. Hannover 1977.

Received February 7, 1991

Revision accepted September 10, 1991 